\title{
Optimum Plot Size for Experimental Cassava Production
}

\author{
Roberto Pequeno de Sousa ${ }^{1}$, Janilson Pinheiro de Assis ${ }^{1}$, Walter Martins Rodrigues ${ }^{2}$, \\ Paulo César Ferreira Linhares ${ }^{1}$, Eudes de Almeida Cardoso ${ }^{1}$, Maria Francisca Soares Pereira ${ }^{3}$ \\ \& José Aluisio de Araújo Paula ${ }^{4}$
}

${ }^{1}$ Jitirana Research Group, Department of Agronomic and Forestry Sciences, Federal Rural Semi-Arid University, Mossoró, RN, Brazil

${ }^{2}$ Center of Exact and Natural Sciences, Federal Rural Semi-Arid University, Mossoró, RN, Brazil

${ }^{3}$ Green Group of Agroecology and Bees, Pombal, PB, Brazil

${ }^{4}$ Brazilian Service to Support Micro and Small Enterprises, Mossoró, RN, Brazil

Correspondence: Roberto Pequeno de Sousa, Jitirana Research Group, Department of Agronomic and Forestry Sciences, Federal Rural Semi-Arid University, Mossoró, RN, 59625-900, Brazil. E-mail: rpequeno@ufersa.edu.br

\begin{tabular}{|c|c|c|}
\hline Received: July 9, 2018 & Accepted: August 10, 2018 & Online Published: September 15, 2018 \\
\hline doi:10.5539/jas.v10n10p231 & URL: https://doi.org & 539/jas.v10n10p231 \\
\hline
\end{tabular}

\begin{abstract}
This work aimed to determine the appropriate size of a plot for evaluation of cassava production. We performed a uniformity trial with the Mastruço cassava variety, in Pacajús, Ceará, Brazil, under dry conditions. Forty plants were cultivated at a spacing of $1.00 \mathrm{~m} \times 0.60 \mathrm{~m}$, in 15 rows. We manipulated 23 different plot sizes. The optimum size of the experimental plot was estimated by the maximum curvature method and the linear-plateau segment regression. We found an optimal plot size of $5.59 \mathrm{~m}^{2}$ for cassava production, what is lower than the size generally used in cassava studies.
\end{abstract}

Keywords: Manihot esculenta C., maximum curvature method, plateau model

\section{Introduction}

Cassava (Manihot esculenta Crantz) has high adaptability to the soil and climatic conditions and excellent starch production per unit of area, essential characteristics for the global socioeconomic situation. The Northeast region is the largest producer in Brazil.

Cassava presents large genetic variability (Bellotti \& Kawano, 1983). The genetic diversity and the differences in vigor and production in the same variety (Lozano et al., 1977) difficult the establishment of an optimal plot size for field experiments. At Brazil, the fourth world producer of cassava (FAO, 2016), experiments are done in different environments, and the heterogeneity of local conditions has led to experimental errors and the absence of differences between treatments.

Experiments should be able to detect small variations in production, and the challenge is to increase the precision of the experiments allowing advances in the selection of varieties, high productivity and better quality of the crop. An efficient planning and a suitable plot size are critical for a high-precise experiment (Silva, 2009).

Plot size increases with the progress of the selection of the plant variety. Advances in selection lead to the reduction in the variability of the population, requiring a larger number of plants to detect variations (Moraes, 2013). When the increase in plot size no longer results in increased precision is needed a higher number of repetitions (Cargnelutti Filho et al., 2012).

The soil heterogeneity is a crucial factor in determining the size and shape of the plot and is essential information for conducting experiments (Storck et al., 2006). Therefore, this work aimed to determine the size of the plot for cassava production for experiments, using the maximum curvature method and the linear-plateau segment regression, which determine the optimal size of the plot that stabilizes the coefficient of variation to a minimum.

\section{Material and Methods}

Data were obtained from a uniformity trial (blank test) with the 'Mastruço' cassava variety, traditionally cultivated by farmers in the Northeast Region of Brazil, conducted at the Unidade de Pesquisa do Litoral da 
Empresa de Pesquisa Agropecuária do Ceará (EPACE), located at Pacajus, Ceará, Brazil $\left(4^{\circ} 10^{\prime} \mathrm{S}\right.$ and $38^{\circ} 27^{\prime} \mathrm{W}$, and $60 \mathrm{~m}$ of altitude).

The soil is Red-Yellow Podzolic Dystrophic with sandy texture (Jacomine et al., 1973). The region has two seasons (rain season from January to June, and a dry season from July to December) the average annual precipitation is $1027 \mathrm{~mm}$ and with a maximum averages temperature of $32{ }^{\circ} \mathrm{C}$, minimum of $23{ }^{\circ} \mathrm{C}$ and an annual average of $26.5^{\circ} \mathrm{C}$. The average relative humidity of the air varies from $70 \%$ during the dry season to $90 \%$ in the rainy season (Frota et al. 1984).

Fifteen rows of $24 \mathrm{~m}$ long with 40 plants each were planted at a spacing of $1.0 \times 0.60 \mathrm{~m}$, covering a total area of $360 \mathrm{~m}^{2}$. Six hundred basic units (BUs) where cassava production was harvested, in $\mathrm{g} \mathrm{plant}^{-1}$, each consisting of $1.0 \times 0.60 \mathrm{~m}$ (1 plant), with an area of $0.6 \mathrm{~m}^{2}$.

Each plot size was constituted by $\mathrm{X}_{1}$ basic units of width (lines) and $\mathrm{X}_{2}$ basic units of length (columns), formed by the grouping of contiguous basic units. The product $\mathrm{X}_{1} * \mathrm{X}_{2}$ corresponded to the plot size $\mathrm{X}$ (in basic units).

Only the basic units that use all the plot area were regarded. The total area of the experiment limited the number of repetitions of each size. Thirty-one basic units groups were used: $1 \times 1,1 \times 2,1 \times 4,1 \times 5,1 \times 8,1 \times 10,1 \times$ $20,1 \times 40,3 \times 1,3 \times 2,3 \times 4,3 \times 5,3 \times 8,3 \times 10,3 \times 20,3 \times 40,5 \times 1,5 \times 2,5 \times 4,5 \times 5,5 \times 8,5 \times 10,5 \times 20$, $5 \times 40,15 \times 1,15 \times 2,15 \times 4,15 \times 5,15 \times 8,15 \times 10$ and $15 \times 20$. The arithmetic mean of the coefficients of variation of the plots of different shapes, but with the same size, were calculated to obtain 23 different plot sizes (X): 1, 2, 3, 4, 5, 6, 8, 10, 12, 15, 20, 24, 25, 30, 40, 50, 60, 75, 100, 120, 150, 200 and 300 basic units, corresponding, respectively to $0.60,1.20,1.80,2.40,3.00,3.60,4.80,6.00,7.20,9.00,12.00,14.40,15.00,18.00$, $24.00,30.00,36.00,45.00,60.00,72.00,90.00,120.00$ and $180.00 \mathrm{~m}^{2}$.

For each plot $(\mathrm{X})$ we calculated:

$$
\mathrm{N}=\frac{600}{\mathrm{X}}
$$

(Number of plots with X basic unit sizes);

$$
\mathrm{S}_{\mathrm{x}}^{2}=\frac{\sum\left[\mathrm{x}_{\mathrm{i}}-M(X)\right]^{2}}{\mathrm{~N}-1}
$$

(Variance between plots of $\mathrm{X}$ basic units of sizes, where $\mathrm{x}_{\mathrm{i}}$ is the cassava production of the $\mathrm{i}$-th plot), and

$$
\mathrm{M}(\mathrm{X})=\frac{\sum_{\mathrm{i}} \mathrm{x}_{\mathrm{i}}}{\mathrm{N}}
$$

( $\mathrm{M}$, the average cassava production of plots of $\mathrm{X}$ basic unit sizes), and

$$
\mathrm{CV}(\mathrm{X})=\frac{\sqrt{S_{X}^{2}}}{M(X)} \times 100
$$

(Coefficient of variation between plots of $\mathrm{X}$ basic unit sizes). The parameters A and $\mathrm{B}$ were estimated to relate the coefficient of variation and plot size:

$$
\mathrm{CV}(\mathrm{X})=\frac{\mathrm{A}}{\mathrm{X}^{\mathrm{B}}}
$$

$\mathrm{A}$, and $\mathrm{B}$ were estimated using the least squares method weighted by the degree of freedom.

With A and B we estimated the optimal plot size using the modified maximum curvature method (Meier \& Lessman, 1971):

$$
X_{M C}=\left[\frac{\hat{A}^{2} \hat{B}^{2}(2 \hat{B}+1)}{\hat{B}+2}\right]^{\frac{1}{2 \hat{B}+2}}
$$

$X_{M C}$ is the value of the abscissa corresponding to the point of maximum curvature (i.e. optimal plot size) and, $\hat{A}$ and $B$ the model estimates for $\mathrm{A}$ and $\mathrm{B}$ (Equation 5).

We also used the linear-plateau segment regression to determine the optimum plot size (Ferreira, 2007; Paranaíba et al., 2009a; 2009b):

$$
\mathrm{CV}(\mathrm{X})= \begin{cases}\beta_{0}+\beta_{1} \mathrm{X}+\varepsilon_{\mathrm{X}} & \text { if } \mathrm{X} \leq \mathrm{X}_{0} \\ \mathrm{CVP}+\varepsilon_{\mathrm{X}} & \text { if } \mathrm{X}>\mathrm{X}_{0}\end{cases}
$$


$\mathrm{CV}(\mathrm{X})$ is the coefficient of variation of each plot size $\mathrm{X} . \mathrm{X}$ is the size of the plot in number of basic units, using the 600 basic units of total area. $\mathrm{X}_{0}$ is the optimal plot size where the linear model reaches a plateau. CVP is the coefficient of variation at the point corresponding to the plateau. $\beta_{0}$, and $\beta_{1}$ are the intercept and the slope, respectively. $\varepsilon_{\mathrm{x}}$, the error associated with $\mathrm{CV}(\mathrm{X})$ supposedly independent and with a normal distribution (zero mean and constant variance $\sigma_{\varepsilon}^{2}$ ).

Both segments, the linear and plateau, shall be equalized at the point $\mathrm{X}_{0}$. Thus, for $\beta_{0}+\beta_{1} X_{0}=\mathrm{CVP}$, the optimal plot size is estimated by the expression:

$$
X_{0}=\frac{\left(C V P^{\prime}-\beta_{0}^{\prime}\right)}{\beta_{1}^{\prime}}
$$

$C V P^{\prime}, \beta_{0}{ }^{\prime}$, and $\beta_{1}^{\prime}$ are estimates of $C V P, \beta_{0}$ and $\beta_{1}$.

The model was adjusted by the least squares method for non-linear regression. All statistical analyzes were performed using the software R (R Development Core Team, 2018).

\section{Results and Discussion}

We found the highest value of $\mathrm{CV}$ at the smallest plot size, i.e., 1 basic unit (Table 1). The CV reduced non-linearly with the increase in plot size (Table 1). The non-linear relation means that any area increment at small plot sizes leads to a higher gain in precision than increments in large plot sizes, i.e. there is little gain in precision by increasing the size of large plots after reaching the optimum size (Henrique Neto et al., 2004; Donato et al., 2008; Oliveira et al., 2011; Humada-González et al., 2013; Brum et al. 2016; Sousa et al., 2016).

Table 1. Size and number of plots, degree of freedom and coefficient of variation among plots to estimate the optimum plot size ${ }^{1}$

\begin{tabular}{llll}
\hline Plot Size (number of basic units) & Number of Plots & Degree of Freedom & Coefficient of Variation (\%) \\
\hline 1 & 600 & 599 & 41.28 \\
2 & 300 & 299 & 30.50 \\
3 & 200 & 199 & 24.35 \\
4 & 150 & 149 & 22.72 \\
5 & 120 & 119 & $19.86^{*}$ \\
6 & 100 & 99 & 17.49 \\
8 & 75 & 74 & 14.27 \\
10 & 60 & 59 & $13.22^{*}$ \\
12 & 50 & 49 & 13.53 \\
15 & 40 & 39 & $12.14^{*}$ \\
20 & 30 & 29 & $10.38^{*}$ \\
24 & 25 & 24 & 6.19 \\
25 & 24 & 23 & 9.64 \\
30 & 20 & 19 & $7.32^{*}$ \\
40 & 15 & 14 & $5.76^{*}$ \\
50 & 12 & 11 & 6.23 \\
60 & 10 & 9 & $5.92^{*}$ \\
75 & 8 & 7 & 5.96 \\
100 & 6 & 5 & 5.69 \\
120 & 5 & 4 & $2.82^{*}$ \\
150 & 2 & 1 & 4.56 \\
200 & 5 & 4.01 \\
300 & 3 & 497 \\
\hline
\end{tabular}

Note. ${ }^{1}$ Basic unit $=0.60 \mathrm{~m}^{2}(1.00 \mathrm{~m} \times 0.60 \mathrm{~m}) ;$ Arithmetic mean of the coefficients of variation of plots of different shapes, but with the same size. 
Optimum plot size, coefficient of variation at the point of maximum curvature and determination coefficient estimated by the modified maximum curvature method were, respectively, 7.02 basic units $\left(4.21 \mathrm{~m}^{2}\right), 16.29 \%$ and $98.50 \%$ (Table 2 ).

Table 2. Parameters estimated by the maximum curvature method, $\hat{A}, \hat{B}$, optimal plot size $\left(\mathrm{X}_{\mathrm{MC}}\right)$ and coefficient of variation at the point of maximum curvature $\left(\mathrm{CV}_{\mathrm{MC}}\right)$, and the coefficient of determination $\left(\mathrm{R}^{2}\right)$ for cassava production $^{1}$

\begin{tabular}{lllll}
\hline$\hat{A}$ & $\hat{B}$ & $\mathrm{X}_{\mathrm{MC}}(\mathrm{UBs})$ & $\mathrm{CV}_{\mathrm{MC}}(\%)$ & $\mathrm{R}^{2}(\%)$ \\
\hline 41.86 & 0.4843 & 7.02 & 16.29 & 98.50
\end{tabular}

Note. ${ }^{1}$ Basic unit $=0.60 \mathrm{~m}^{2}(1.00 \mathrm{~m} \times 0.60 \mathrm{~m})$.

The coefficient of determination indicated an optimal adjustment of the equation to the data, i.e., a large part of the variation of the data was explained by the regression equation and, consequently, showed high reliability in the plot size estimation. Viana et al. (2002) obtained a much larger plot size $\left(24.00 \mathrm{~m}^{2}\right)$ using the same method. The discrepancy was probably due to the higher size of the basic unit adopted $\left(4.80 \mathrm{~m}^{2}\right)$ than the one used in this study $\left(0.60 \mathrm{~m}^{2}\right)$. According to Federer (1955), Cargnelutti Filho et al. (2016a), Cargnelutti Filho et al. (2016b), Facco et al. (2017) and Giovani et al. (2018) the size adopted for the basic unit influences the size of the estimated plot.

The plot size estimated by the maximum curvature method for cassava cultivation may be adequate. Although, according to Henriques Neto et al. (2004) and Brito et al. (2012), the region immediately above the point of maximum curvature $\left(\mathrm{X}_{\mathrm{MC}}\right)$ still shows a considerable reduction in the values of the coefficient of variation with the increase of the plot size. The value of the abscissa at the point of maximum curvature should be interpreted as the minimum limit of the plot size, and not as the optimal size since the value tends to occur in the region of small plots (Chaves, 1985). Therefore, Lessman and Atkins (1963) proposed the notation of critical point instead of optimal point.

Low estimates for the sample size or size of plots by the maximum curvature method are common in the literature (Viana et al., 2002; Henriques Neto et al., 2004; Leite et al., 2006; Donato et al., 2008; Silva, 2009; Brito et al., 2012; Humada-González et al., 2013). However, the maximum curvature method is indicated as the most suitable method for plot size estimation (Zanon \& Stork, 2000; Viana et al., 2002; Lopes et al., 2005; Donato et al., 2008).

According to Lima et al. (2007), the modified maximum curvature method establishes a regression equation with a high coefficient of determination, as found here, thus increasing the reliability of the estimates. Nevertheless, the method does not consider the experimental costs, but if costs are not high they can be neglected (Lima et al., 2007).

The behavior between CV and plot size was the same as that described in the modified maximum curvature method.

The plot size, the coefficient of variation at the plateau point and the determination coefficient, obtained by the linear-plateau segment regression were, respectively, 8.90 UBs $\left(5.34 \mathrm{~m}^{2}\right), 5.55 \%$ and $88.43 \%$ (Table 3). The magnitude of the coefficient of determination indicated a good fit of the model to the data, which also revealed a high reliability in the plot size estimation. The behavior between $\mathrm{CV}$ and plot size was the same as that described using the modified maximum curvature method.

Table 3. Estimated parameters by the linear-plateau segment regression: $\beta_{0}$ and $\beta_{1}$, the coefficient of variation of a plot $(C V P)$, the abscissa or plot size at the plateau point, and the coefficient of determination for cassava production $^{1}$

\begin{tabular}{llllll}
\hline \multicolumn{3}{c}{ Estimated parameters } & \multirow{2}{*}{$\mathrm{CV}_{1}(\%)$} & Plot size (Basic units) & $\mathrm{R}^{2}(\%)$ \\
\hline$\beta_{0}{ }^{\prime}$ & $\beta_{1}{ }^{\prime}$ & $C V P^{\prime}(\%)$ & & \\
\hline 39.39 & -3.49 & 6.88 & 35.89 & 9.32 & 88.38 \\
\hline
\end{tabular}

Note. ${ }^{1}$ Basic unit $=0.60 \mathrm{~m}^{2}(1.00 \mathrm{~m} \times 0.60 \mathrm{~m})$. 
The linear-plateau segment regression estimated a plot size $\left(5.59 \mathrm{~m}^{2}\right)$ slightly larger than the modified maximum curvature method $\left(4.21 \mathrm{~m}^{2}\right)$, presenting a good precision $\left(C V P^{\prime}=6.88 \%\right)$ and fit to the data $\left(\mathrm{R}^{2}=88.38 \%\right)$. Several studies also found a larger estimation of plot size by the linear-plateau model than the maximum curvature method (Paranaíba et al., 2009b; Silva, 2009; Oliveira et al., 2011; Brito et al., 2012). According to Brito et al. (2012), the abscissa value of the maximum curvature point tends to occur in the region of smaller plot sizes leading to smaller estimations.

Our results show that the size of a plot can be significantly reduced (between 4.21 and $5.59 \mathrm{~m}^{2}$ ) concerning other studies (Alves et al., 2011) without compromising the outcome.

Using more than one method to measure the optimum size of a plot reinforce the results since each method has its peculiarity (Silva, 2009; Lorentz et al., 2012; Lúcio et al., 2012; Moraes, 2013; Sousa et al., 2015). Adopting the law of minimum (Moraes, 2013), the optimal size of plots for evaluation of cassava production is 9.32 basic units of useful area $\left(5.59 \mathrm{~m}^{2}\right)$.

\section{Conclusions}

The modified maximum curvature method and linear-plateau segment regression model estimated optimum plot sizes of 4.21 and $5.59 \mathrm{~m}^{2}$, respectively, for experiments of cassava production.

The linear-plateau segment model presented a better estimation of optimal plot size to evaluate cassava production.

\section{References}

Alves, M. C. S., Carvalho, H. W. L., Rangel, M. A. S., Santos, V. S., Silva, J., \& Rodrigues, C. S. (2011). Comportamento de cultivares de mandioca no Rio Grande do Norte (p. 5). Retrieved from https://www. ainfo.cnptia.embrapa.br/digital/bitstrea/item/54034/1/comportamento-de-cultivares-resumo-n.-127

Bellotti, A. C., \& Kawano, K. (1983). Mejoramiento para resistencia varietal en el cultivo de la yuca. Centro Internacional de Agricultura Tropical. Yuca, control integrado de plagas (pp. 171-194). Cali, Colombia: CIAT/PNUD.

Brito, M. C. M., Faria, G. A., Morais, A. R., Souza, E. M., \& Dantas, J. L. L. (2012). Estimação do tamanho ótimo de parcela via regressão antitônica. Revista Brasileira de Biometria, 30(3), 353-366.

Brum, B., Brandelero, F. D., Oliveira Vargas, T. de., Storck, L., \& Zanini, P. P. G. (2016). Tamanho ótimo de parcela para avaliação da massa e diâmetro de cabeças de brócolis. Ciência Rural, 46(3), 447-463. https://doi.org/10.1590/0103-8478cr20150236

Cargnelutti Filho, A., Marchesan, E., Silva, L. S., \& Toebe, M. (2012). Medidas de precisão experimental e número de repetições em ensaios de genótipo de arroz irrigado. Pesquisa Agropecuária Brasileira, 47(3), 336-343. https://doi.org/10.1590/S0100-204X2012000300004

Cargnelutti Filho, A., Alves, B. M., Toebe, M., \& Facco, G. (2016a). Tamanhos de unidades experimentais básicas e de parcelas em tremoço branco. Ciência Rural, 46(4), 610-618. https://doi.org/10.1590/ 0103-8478cr20150756

Cargnelutti Filho, A., Storck, L., Lúcio, A. D., Toebe, M., \& Alves, B. M. (2016b). Tamanho de unidades experimentais básicas e tamanho ótimo de parcelas para nabo-forrageiro. Pesquisa Agropecuária Brasileira, 51(4), 309-319. https://doi.org/10.1590/S0100-204X2016000400003

Chaves, L. J. (1985). Tamanho de parcela para seleção de progênies de milho (Zea mays L.) (148f. Tese (Doutorado em Genética e Melhoramento de Plantas), Escola Superior de Agricultura Luiz de Queiroz, Universidade de São Paulo). Retrieved from https://www.bdpa.cnptia.embrapa.br/consulta/busca?b=ad...

Donato, S. L. R., Siqueira, D. L., Silva, S. D. E. O., Cecon, P. R., Silva, J. A., \& Salomão, L. C. C. (2008). Estimativas de tamanho de parcelas para avaliação de descritores fenotípicos em bananeira. Pesquisa Agropecuária Brasileira, 43(8), 957-969. https://doi.org/10.1590/S0100-204X2008000800003

Facco, G., Cargnelutti Filho, A., Alves, B. M., Lavezo, A., Follmann, D. N., Bem, C. M., ... Wartha, C. A. (2017). Basic experimental unit and plot sizes with the method of maximum curvature of the coefficient of variation in sunn hemp. African Journal of Agricultural Research, 12(6), 415-423. https://doi.org/10.5897/ AJAR2016.11814

Faco, G., Cargnelutti Filho, A., Lavezo, F., Schabarum, D. E., Chaves, G. G., \& Silveira, D. L. (2018). Tamanhos de unidade experimental básica e de parcela para massa de matéria verde de Crotalária juncea. Ciências Rural, 48(5), 1-9. 
FAO. (2016). FAOSTAT. Statistics Division, FAO. Retrieved from http://www.faostat3.fao.org/home/E

Federer, W. T. (1955). Experimental design (p. 544). New York: The Macmillan Company. Retrieved from https://academic.oup.com/ajae/article/38/3/882/121601

Ferreira, D. F. (2007). Uso de recursos computacionais (p. 157). Lavras: Universidade Federal de Lavras. Retrieved from https://dex.ufla.br/danielff/meusarquivospdf/rco.pdf

Frota, P. C. E., Parente, J. I. G., Costa, J. T. A., \& Melo, F. I. O. (1984). Influência de fatores climáticos nas fenofases cajueiro. Trabalho apresentado no 1 Encontro Nacional de Agroindústria do Caju e $28^{\circ}$ Semana Cearense do Caju, Fortaleza, Ce. Retrieved from https://www.ccarevista.ufc.br/site/down.php?arq=02rca 24.pdf

Henriques Neto, D., Sediyama, T., Souza, M. A., Cecon, P. R., Yamanaka, C. H., Sediyama, M. A. N., \& Viana, A. E. S. (2004). Tamanho de parcelas em experimentos com trigo irrigado sob plantio direto e convencional. Pesquisa Agropecuária Brasileira, 39(6), 517-524. https://doi.org/10.1590/S0100-204X2004000600001

Humada-González, G. G., Liska, G. R., Mendoza, C. A. C., \& Morais, A. R. (2013). Métodos de estimação de tamanho ótimo de parcela em experimento com batata. Reunião Anual da Região Brasileira da Sociedade Internacional de Biometria, 58 a , e Simpósio de Estatística Aplicada à Experimentação Agronômica, $15^{\circ}$, Campina Grande. Anais... Campina Grande: UEPB. Retrieved from https://www.escavador.com/sobre/ 2885649/gustavo-henrique-esteves

Jacomine, P. R. T., Almeida, J. C., \& Medeiros, L. A. R. (1973). Levantamento exploratório-Reconhecimento de solos no Estado do Ceará. Recife, Ministério da Agricultura-Divisão de Pesquisa pedológica, 2 (Boletim Técnico, 28). Retrieved from https://www.infoteca.cnptia.embrapa.br/infoteca/bitstream/doc/.../2/BT26 VolumeI.pdf

Leite, M. S. O., Peternelli, L. A., Barbosa, M. H. P. (2006). Effects of plot size on the estimation of genetic parameters in sugarcane families. Crop Breeding and Applied Biotechnology, 34(6), 40-46. https://doi.org/ 10.12702/1984-7033.v06n01a06

Lessman, K. J., \& Atkins, R. E. (1963). Optimum plot size and relative efficiency of lattice designs for grain sorghum yield tests. Crop Science, 3(5), 477-481. https://doi.org/10.2135/cropsci1963.0011183X000300 $060006 x$

Lima, J. F., Peixoto, C. P., Ledo, C. A. S., \& Faria, G. A. (2007). Tamanho ótimo de parcela para experimentos com plantas de mamoeiro em casa de vegetação. Ciência e Agrotecnologia, 31(5), 1411-1415. https://doi.org/10.1590/S1413-70542007000500021

Lopes, S. J., Storck, L., Lúcio, A. D., Lorentz, L. H., Lovato. C., \& Dias, V. O. (2005). Tamanho de parcela para produtividade de grãos de sorgo granífero em diferentes densidades de plantas. Pesquisa Agropecuária Brasileira, 40(6), 525-530. https://doi.org/10.1590/S0100-204X2005000600001

Lorentz, L. H., Erichsen, R., \& Lúcio, A. D. (2012). Proposta de método para estimação de tamanho de parcela para culturas agrícolas. Revista Ceres, 59(6), 772-780. https://doi.org/10.1590/S0034-737X2012000600006

Lozano, J. C., Toro, J. C., Castro, A., \& Bellotti, A. C. (1977). Produção de material de plantio de mandioca (p. 28). Cali, Colombia: Centro Internacional de Agricultura Tropical. Retrieved from https://cgspace.cgiar.org/ handle/10568/69720

Lúcio, A. D., Haesbaert, F. M., Santos, D., Schwertner, D. V., \& Brunes, R. R. (2012). Tamanhos de amostras e de parcelas para variáveis de crescimento e produtivas de tomateiro. Horticultura Brasileira, 30(4), 660-668. https://doi.org/10.1590/S0102-05362012000400016

Meier, V. D., \& Lessman, K. J. (1971). Estimation of optimum field plot shape and size for testing yield in Crambe abyssinica Hochst. Crop Science, 11(3), 648-650. https://doi.org/10.2135/cropsci1971.0011183X 001100050013x

Moraes, B. F. X. (2013). Tamanho de parcela e de amostra na avaliação da produtividade de grãos de café arábica (97f. Dissertação (Mestrado em Genética e Melhoramento de Plantas), Universidade Federal de Lavras). Retrieved from https:// www.sbicafe.ufv.br/handle/123456789/6856?show=full

Oliveira, G. M. V., Mello, J. M., Lima, R. R., Scolforo, J. R. S., \& Oliveira, A. D. (2011). Tamanho e forma de parcelas experimentais para Eremanthus erythropappus. Cerne, 17(3), 327-338. https://doi.org/10.1590/ S0104-77602011000300006 
Paranaíba, P. F., Ferreira, D. F., \& Morais, A. R. (2009a). Tamanho ótimo de parcelas experimentais: Proposição de métodos de estimação. Revista Brasileira de Biometria, 27(2), 255-268.

Paranaíba, P. F., Morais, A. R., \& Ferreira, D. F. (2009b). Tamanho ótimo de parcelas experimentais: Comparação de métodos em experimentos de trigo e mandioca. Revista Brasileira de Biometria, 27(1), 81-90.

R Development Core Team. R. (2018). A language and environment for statistical computing. Viena, Austria: R Foundation for Statistical Computing. Retrieved from http://www.cran.r-project.org/src/base/R-3

Silva, J. R. (2009). Tamanho de parcela e efeito de bordadura em experimentos com meloeiro (142f. Tese (Doutorado em Fitotecnia), Universidade Federal Rural do Semi-Árido, Mossoró-RN). Retrieved from http://www.docplayer.com.br/52646910-Jose-robson-da-silva-tama-ho-de-parcela

Sousa, R. P., Silva, P. S. L., Assis, J. P., Silva, J., Oliveira, V. R., \& Oliveira, A. M. P. (2015). Tamanho ótimo de parcela para avaliação do rendimento de grãos do girassol. Revista Brasileira de Engenharia Agrícola e Ambiental, 19(1), 21-26. https://doi.org/10.1590/1807-1929/agriambi.v19n1p21-26

Sousa, R. P., Silva, P. S. L., \& Assis, J. P. (2015). Tamanho e forma de parcelas para experimentos com girassol. Revista Ciência Agronômica, 47(4), 683-690.

Storck, L., Garcia, D. C., Lopes, S. J., \& Estefanel, V. (2016). Experimentação vegetal (3rd ed., p. 198). Santa Maria: UFSM. Retrieved from https://editoraufsm.com.br/experimentac-o-vegetal

Viana, A. E. S., Sediyama, T., Cecon, P. R., Lopes, S. C., \& Sediyama, M. A. N. (2002). Estimativas de tamanho de parcela em experimentos com mandioca. Horticultura Brasileira, 20(1), 58-63. https://doi.org/10.1590/ S0102-05362002000100011

Zanon, M. L. B., \& Storck, L. (2000). Tamanho de parcelas experimentais para Eucaliptus saligna em dois estádios em desenvolvimento. Cerne, 6(2), 104-111.

\section{Copyrights}

Copyright for this article is retained by the author(s), with first publication rights granted to the journal.

This is an open-access article distributed under the terms and conditions of the Creative Commons Attribution license (http://creativecommons.org/licenses/by/4.0/). 